\title{
Aqueous Extract of Agaricus blazei Murrill Prevents Age-Related Changes in the Myenteric Plexus of the Jejunum in Rats
}

\author{
Ana Paula de Santi-Rampazzo, ${ }^{1}$ João Paulo Ferreira Schoffen, ${ }^{2}$ \\ Carla Possani Cirilo, ${ }^{1}$ Mariana Cristina Vicente Umada Zapater, ${ }^{1}$ \\ Fernando Augusto Vicentini, ${ }^{1}$ Andréia Assunção Soares, ${ }^{3}$ Rosane Marina Peralta, ${ }^{3}$ \\ Adelar Bracht, ${ }^{3}$ Nilza Cristina Buttow, ${ }^{1}$ and Maria Raquel Marçal Natali ${ }^{1}$ \\ ${ }^{1}$ Department of Morphological Sciences, State University of Maringá (UEM), 87020-900 Maringá, PR, Brazil \\ ${ }^{2}$ Center of Biological Sciences, State University of the North of Paraná (UENP), Bandeirantes, PR, Brazil \\ ${ }^{3}$ Department of Biochemistry, State University of Maringá (UEM), 87020-900 Maringá, PR, Brazil
}

Correspondence should be addressed to Ana Paula de Santi-Rampazzo; anapaulasanti@gmail.com

Received 8 October 2014; Revised 15 December 2014; Accepted 16 December 2014

Academic Editor: Chunchao Han

Copyright (c) 2015 Ana Paula de Santi-Rampazzo et al. This is an open access article distributed under the Creative Commons Attribution License, which permits unrestricted use, distribution, and reproduction in any medium, provided the original work is properly cited.

\begin{abstract}
This study evaluated the effects of the supplementation with aqueous extract of Agaricus blazei Murrill (ABM) on biometric and blood parameters and quantitative morphology of the myenteric plexus and jejunal wall in aging Wistar rats. The animals were euthanized at 7 (C7), 12 (C12 and CA12), and 23 months of age (C23 and CA23). The CA12 and CA23 groups received a daily dose of $\mathrm{ABM}$ extract $(26 \mathrm{mg} / \mathrm{animal})$ via gavage, beginning at 7 months of age. A reduction in food intake was observed with aging, with increases in the Lee index, retroperitoneal fat, intestinal length, and levels of total cholesterol and total proteins. Aging led to a reduction of the total wall thickness, mucosa tunic, villus height, crypt depth, and number of goblet cells. In the myenteric plexus, aging quantitatively decreased the population of $\mathrm{HuC} / \mathrm{D}^{+}$neuronal and $\mathrm{S} 100^{+}$glial cells, with maintenance of the $\mathrm{nNOS}^{+}$ nitrergic subpopulation and increase in the cell body area of these populations. Supplementation with the ABM extract preserved the myenteric plexus in old animals, in which no differences were detected in the density and cell body profile of neurons and glial cells in the CA12 and CA23 groups, compared with C7 group. The supplementation with the aqueous extract of ABM efficiently maintained myenteric plexus homeostasis, which positively influenced the physiology and prevented the death of the neurons and glial cells.
\end{abstract}

\section{Introduction}

Aging is associated with a progressive decline in physiological function and metabolic processes [1]. The causes of this decline are linked to immune system dysfunction and disorders of energy metabolism that create oxidative stress [2]. Oxidative stress occurs in cell systems whenever the production of free radical molecules exceeds antioxidant capacity. If not removed, free radicals attack and damage proteins, lipids, and nucleic acids, diminishing their activity and leading to losses in energy metabolism, cell signaling, transport, and other important functions [3], in addition to their role in cellular death through necrosis or apoptosis [4]. To minimize the impact of an imbalance between reactive oxygen species and antioxidants, investigations of substances with possible antioxidant capacity have garnered significant scientific interest.

The benefits of ingesting traditional mushrooms are widely recognized, and these mushrooms are used worldwide as food supplements. To evaluate their effects, studies have been performed using basidiomycetes, particularly the species Agaricus blazei Murrill (ABM; known popularly as cogumelo do sol). These studies have focused on both nutritional and pharmacological objectives and assessed possible 
antioxidant properties and the prevention of various diseases, including cancer, diabetes, hyperlipidemia, arteriosclerosis, and chronic types of hepatitis [5].

Variations occur in the gastrointestinal tract during development and senescence. These changes involve structural and functional changes, such as decreases in the frequency and amplitude of peristaltic movements, digestion, nutrient absorption, and cell immunity [6, 7]. Although some studies have suggested maintenance of the structure of the intestinal tunica during aging [8], other reports have indicated that aging can alter villus height, crypt depth, and muscle layer thickness $[9,10]$.

Functional impairment of the gastrointestinal tract is directly linked to changes in extrinsic nerve components (i.e., sympathetic and parasympathetic peripheral nerve fibers) and an intrinsic component (i.e., the enteric nervous system [ENS]). This system modulates complex functions, such as motility, secretion, and blood flow. It consists of a ganglionated plexus and two ganglionated plexi: the myenteric plexus (with ganglia located between the layers of smooth muscle of the muscular tunica) and the submucosal plexus (which has its ganglia in the submucosal tunica) [11].

Aging causes a reduction of the number of neurons in the ENS. This loss is associated with not only an increase in free radicals [12] but also a reduction of neurotrophic factors that originate in glial cells, which are essential for neuronal development and maintenance [13]. Moreover, previous studies have found significant age-related increases in cell body area $[8,14]$, which may be justified by rearrangement of the remaining neurons, demonstrating the neuroplasticity of fully differentiated tissue.

Considering the possible antioxidant potential of edible and medicinal mushrooms, the objective of the present study was to evaluate the effects of an aqueous extract of Agaricus blazei on the morphology and intrinsic innervation of the intestine and myenteric plexus in aging rats.

\section{Materials and Methods}

2.1. Obtaining Agaricus Blazei Murrill (ABM) Extract. The present study used dehydrated basidiomes of ABM produced in Ibema, PR, Brazil ( $25^{\circ} 6^{\prime} 50^{\prime \prime}$ south, $53^{\circ} 0^{\prime} 53^{\prime \prime}$ west). The basidiomes were milled to form a fine powder and then subjected to aqueous extraction, modified from the methodology of Soares et al. [15]. Distilled water $(100 \mathrm{~mL})$ was added to every $10 \mathrm{~g}$ of milled basidiome, which remained under agitation at $28^{\circ} \mathrm{C}$ for $3 \mathrm{~h}$. The residual solids were removed by vacuum filtration using size-1 Whatman filter paper and again subjected to extraction, which was repeated three times. The filtrates were lyophilized and kept in a freezer at $-20^{\circ} \mathrm{C}$. The chemical characterization of aqueous extract of the Agaricus blazei is described by Soares [16].

2.2. Animals. Starting at 7 months of age, 25 male Wistar rats (Rattus norvegicus) were housed in polypropylene boxes (four individuals per box) in the Animal House in the Morphological Sciences Department under a $12 \mathrm{~h} / 12 \mathrm{~h}$ light/dark cycle at $22 \pm 2^{\circ} \mathrm{C}$. The rats were assigned to five groups: 7 months of age (C7), 12 months of age (C12 and CA12), and 23 months of age (C23 and CA23). All of the procedures in this study that involved the use of animals were approved by the Committee for Ethics in Animal Experimentation of Maringá State University (procedure number 063/2010).

2.3. Treatment and Euthanasia. The animals were fed ad libitum with standard rodent chow (NUVILAB, NUVITAL). The rats in the CA12 and CA23 groups were supplemented daily via gavage with $1 \mathrm{~mL}$ of an aqueous solution that contained $26 \mathrm{mg}$ of freeze-dried ABM beginning at 7 months of age.

The study evaluated body weight, food intake by offering $100 \mathrm{~g}$ daily per animal and calculating the remainder, and water intake by offering $300 \mathrm{~mL}$ per day and calculating the remainder throughout the experimental period. At 7, 12, and 23 months of age, the animals intravenously received vincristine sulfate $(0.5 \mathrm{mg} / \mathrm{kg}$ body weight), a protein synthesis blocker, $2 \mathrm{~h}$ prior to euthanasia. The injections occurred at the same time each day (6:00 AM) in all of the experiments to avoid circadian variations.

Afterwards, the animals were intraperitoneally anesthetized with sodium thiopental (Thionembutal, Abbott Laboratories, North Chicago, IL, USA) at a dose of $40 \mathrm{mg} / \mathrm{kg}$ of body weight, and the nasoanal length was measured to determine the Lee index (body weight ${ }^{1 / 3}(\mathrm{~g}) /$ nasoanal length $(\mathrm{cm}) \times 1000)$. Following blood collection by cardiac puncture for biochemical analyses, the animals were euthanized by an overdose of anesthetic. Laparotomy was performed to remove and measure the length of the small intestine and weigh periepididymal and retroperitoneal adipose tissues. Jejunum samples were sent for histological processing and immunohistochemical techniques to study the myenteric plexus.

2.4. Biochemical Analysis of Blood Components. For the analysis of total proteins, albumin, globulins, triglycerides, and total cholesterol, blood was collected and placed in a test tube to obtain serum. To measure glucose levels, the blood was kept in a test tube that contained ethylenediaminetetraacetic acid (EDTA) fluorinated at a rate of $50 \mu \mathrm{L} / 3 \mathrm{~mL}$ to obtain plasma and nonfluorinated EDTA to analyze aspartate aminotransferase (AST) and alanine aminotransferase (ALT) enzymes and total plasma antioxidant capacity (TAC-ABTS $\left[2,2^{\prime}\right.$-azino-di(3-ethylbenzthiazoline-6-sulfonic acid) $]$ ). The samples were centrifuged at 3000 rotations per minute for $15 \mathrm{~min}$, and the levels were determined using Analisa kits (Gold Analisa Diagnóstica Ltda, Minas Gerais, Brazil). TACABTS was assessed according to the methodology described by Erel [17].

2.5. Tissue Processing and Histological Analysis. Samples of the jejunum were opened at the mesenteric border, fixed in Bouin's solution $(750 \mathrm{~mL}$ saturated picric acid solution, $250 \mathrm{~mL}$ formaldehyde, and $50 \mathrm{~mL}$ glacial acetic acid) for $6 \mathrm{~h}$, stored in $70 \%$ alcohol, and subjected to the following procedures.

2.5.1. Paraffin Inclusion. The jejunum samples were dehydrated in a series of increasing alcohol concentrations, cleared 
in xylol, and embedded in paraffin to obtain $7 \mu \mathrm{m}$-thick semiserial histological sections using a Leica RM 2145 microtome. These sections were then stained with hematoxylineosin (H\&E) to evaluate the thickness of the mucosa tunic, muscular coat, and total intestinal wall.

Morphometric analyses were performed by sampling images captured using a 10x lens on an Olympus BX41 optical microscope coupled to a high-resolution Olympus Q Color 3 camera. Thicknesses were estimated by measuring 10 random points per section, for a total of 100 measurements per animal, using ImagePro Plus 4.5 image analysis software (Media Cybernetics). The results are expressed as micrometers.

2.5.2. Historesin Inclusion. The jejunum samples were dehydrated in $95 \%$ alcohol, 100\% alcohol, and 100\% alcohol + infiltration solution (resin activator) at a ratio of $1: 1$ and stored overnight at $-4^{\circ} \mathrm{C}$ in infiltration solution. The samples were then placed inside specific containers with solution for inclusion (infiltration solution + hardener) and oven-dried at $37^{\circ} \mathrm{C}$ for approximately 10 days. The blocks were then subjected to microtomy to obtain $2.5 \mu \mathrm{m}$-thick semiserial sections, stained with $\mathrm{H} \& \mathrm{E}$ to morphometrically analyze the villi, intestinal crypts, and metaphase index (MetI), and then subjected to the periodic acid-Schiff (PAS) histochemical technique to identify globet cells.

(1) Measuring Villi and Intestinal Crypts. The heights of 90 villi and 90 crypts per animal were measured longitudinally from images of the mucosa captured using a 10x lens on an Olympus BX41 optical microscope coupled to a highresolution Olympus Q Color 3 camera with ImagePro Plus 4.5 image analysis software (Media Cybernetics). The results are expressed as micrometers.

(2) Metaphase Index. The MetI is expressed as the percentage of metaphase nuclei divided by the total number of counted nuclei obtained in longitudinal crypts with visible lumen. A total of 2,500 cells per animal were quantified using an Olympus BX41 light microscope (Tokyo, Japan) with a 40x lens. The MetI was multiplied by Tannok's constant $(\mathrm{Kt}=$ 0.57 ) to correct tissue geometry and avoid overestimating the number of metaphases [18]. The following equation was used to calculate the MetI: MetI $=$ number of cells in metaphase $\times$ $100 \times \mathrm{Kt} /$ total number of cells in crypts.

(3) Histochemical Analysis of Globet Cells. The semiserial sections were subjected to the PAS histochemical technique to quantify the population of goblet cells in 50 microscopic fields $\left(0.352 \mathrm{~mm}^{2} /\right.$ field $)$ per animal. The quantitative analyses were performed with images obtained with an Olympus BX41 optical microscope coupled to a high-resolution Olympus Q Color 3 camera. The cells were counted with the aid of ImagePro Plus 4.5 software (Media Cybernetics).

\subsection{Morphoquantitative Analysis of the Myenteric Plexus}

2.6.1. Obtaining Membrane Preparations. Jejunum samples were washed with $0.1 \mathrm{M}$ phosphate-buffered saline (PBS; $\mathrm{pH}$ 7.4) to remove any residue, filled with Zamboni's fixative, tied
TABLE 1: Characteristics of primary and secondary antibodies used for immunohistochemical analysis.

\begin{tabular}{lccc}
\hline $\begin{array}{l}\text { Primary } \\
\text { antibody }\end{array}$ & Supplier & Dilution & $\begin{array}{c}\text { Secondary } \\
\text { antibody }^{*}\end{array}$ \\
\hline $\begin{array}{l}\text { Anti-HuC/HuD } \\
\text { (mouse) }\end{array}$ & $\begin{array}{c}\text { Invitrogen, USA } \\
\text { Santa Cruz }\end{array}$ & $1: 500$ & $\begin{array}{c}\text { Alexa fluor 488 } \\
\text { (anti-mouse) }\end{array}$ \\
$\begin{array}{l}\text { Anti-nNOS } \\
\text { (rabbit) }\end{array}$ & $\begin{array}{c}\text { Biotechnology, } \\
\text { USA }\end{array}$ & $1: 500$ & $\begin{array}{c}\text { Alexa fluor 546 } \\
\text { (anti-rabbit) }\end{array}$ \\
$\begin{array}{l}\text { Anti-S-100 } \\
\text { (rabbit) }\end{array}$ & Sigma, USA & $1: 200$ & $\begin{array}{c}\text { Alexa fluor 546 } \\
\text { (anti-rabbit) }\end{array}$ \\
\hline
\end{tabular}

${ }^{*}$ The secondary antibodies were utilized with 1:500 dilution and supplied by Invitrogen, USA.

at the end, submerged in the same fixative, and kept in cool storage for $18 \mathrm{~h}$. They were then opened and subjected to dehydration using increasing concentrations of alcohol ( $95 \%$ and $100 \%)$, cleared in xylol, and rehydrated in a decreasing series of alcohol concentrations $(100 \%, 90 \%, 80 \%$, and $50 \%)$. They were then stored in $0.1 \mathrm{M}$ PBS ( $\mathrm{pH} 7.4$ ) with $0.08 \%$ sodium azide at $4^{\circ} \mathrm{C}$. Total preparations of the muscle tunica were obtained by microdissection of the samples with a stereoscope with transillumination to remove the mucosa and submucosa tunics.

2.6.2. Double $H u C / D-n N O S$ and $H u C / D-S 100$ Immunolabeling. The total preparations of the jejunum muscle tunica were subjected to immunohistochemical techniques to detect $\mathrm{HuC} / \mathrm{D}$ protein [19], neuronal nitric oxide synthase (nNOS) enzyme [20], and S100 protein [21]. The membranes were rinsed twice in $0.1 \mathrm{M}$ PBS ( $\mathrm{pH}$ 7.4) with $0.05 \%$ Triton X-100 for $10 \mathrm{~min}$ and immersed for $1 \mathrm{~h}$ in a solution that contained $0.1 \mathrm{M}$ PBS (pH 7.4), $0.05 \%$ Triton X-100, $2 \%$ bovine serum albumin (BSA), and $10 \%$ goat serum to avoid nonspecific binding. The tissues were then incubated for $48 \mathrm{~h}$ in a solution that contained $0.1 \mathrm{M} \mathrm{PBS}$ (pH 7.4) with $0.05 \%$ Triton X-100, $2 \%$ BSA, $2 \%$ goat serum, and primary antibodies (Table 1 ). The membranes were washed three times in $0.1 \mathrm{MPBS}(\mathrm{pH}$ 7.4) with $0.05 \%$ Triton X-100 for $5 \mathrm{~min}$, and incubated for $2 \mathrm{~h}$ at room temperature with secondary antibodies (Table 1 ). The preparations were washed with $0.1 \mathrm{MPBS}(\mathrm{pH}$ 7.4) and arranged between the slides with ultrapure glycerol.

2.6.3. Morphoquantitative Analysis. To quantify the $\mathrm{HuC} / \mathrm{D}^{+}$ myenteric neuron population, $\mathrm{nNOS}^{+}$subpopulation, and $\mathrm{S}-100^{+}$glial cells, all of which are immunofluorescent, an Olympus BX40 light microscope was used, fitted with specific immunofluorescence filters and coupled to a Moticam 2500 camera. The density (expressed as cells $/ \mathrm{cm}^{2}$ ) was calculated by counting neuronal and glial cell bodies in microscopic images (32 images/animal) captured from the middle region $\left(60^{\circ}-120^{\circ} ; 240^{\circ}-300^{\circ}\right)$ of the intestinal circumference, considering $0^{\circ}$ as the mesenteric insertion [22], using a 20x lens. The area of each analyzed image was $0.093 \mathrm{~mm}^{2}$. Neurons and glial cells were also counted in 50 ganglia per animal in the C7, C23, and CA23 groups. For the morphometric analysis, cell body areas $\left(\mu \mathrm{m}^{2}\right)$ were measured in $100 \mathrm{HuC} / \mathrm{D}$ neurons ${ }^{+}$ 
TABLE 2: Body weight (BW), food intake (FI), water intake (WI), Lee index (ILee), weight of periepididymal (PER) and retroperitoneal (RET) fat, total fat $(\Sigma)$, and small intestine length (SIL) in aging rats (C7, C12, and $\mathrm{C} 23$ groups) and aging rats supplemented with the aqueous extract of A. blazei (CA12 and CA23 groups). The results are expressed as mean \pm standard error.

\begin{tabular}{lccccc}
\hline & C7 & C12 & CA12 & C23 & CA23 \\
\hline BW $(g)$ & $489.5 \pm 8.72 \mathrm{a}^{*}$ & $492.9 \pm 4.32 \mathrm{a}$ & $483.7 \pm 8.97 \mathrm{a}$ & $510.3 \pm 7.67 \mathrm{a}$ & $513.5 \pm 3.66 \mathrm{a}$ \\
FI $(\mathrm{g})$ & $28.26 \pm 0.38 \mathrm{a}$ & $21.34 \pm 0.38 \mathrm{~b}$ & $21.92 \pm 0.61 \mathrm{~b}$ & $22.66 \pm 0.47 \mathrm{~b}$ & $24.06 \pm 0.60 \mathrm{~b}$ \\
WI $(\mathrm{mL})$ & $43.7 \pm 1.16 \mathrm{a}$ & $40.11 \pm 2.00 \mathrm{a}$ & $43.0 \pm 4.19 \mathrm{a}$ & $48.45 \pm 1.55 \mathrm{a}$ & $39.0 \pm 2.17 \mathrm{a}$ \\
ILee & $295.6 \pm 2.72 \mathrm{a}$ & $301.7 \pm 3.83 \mathrm{ab}$ & $292.5 \pm 1.47 \mathrm{a}$ & $307.3 \pm 1.55 \mathrm{~b}$ & $308 \pm 0.73 \mathrm{~b}$ \\
PER $(\mathrm{g} / 100 \mathrm{~g})$ & $1.54 \pm 0.18 \mathrm{a}$ & $1.84 \pm 0.04 \mathrm{a}$ & $1.66 \pm 0.19 \mathrm{a}$ & $1.72 \pm 0.15 \mathrm{a}$ & $1.67 \pm 0.11 \mathrm{a}$ \\
RET $(\mathrm{g} / 100 \mathrm{~g})$ & $1.56 \pm 0.15 \mathrm{a}$ & $1.98 \pm 0.17 \mathrm{a}$ & $1.61 \pm 0.24 \mathrm{a}$ & $2.54 \pm 0.15 \mathrm{~b}$ & $2.26 \pm 0.16 \mathrm{ab}$ \\
$\sum(\mathrm{g} / 100 \mathrm{~g})$ & $3.10 \pm 0.32 \mathrm{a}$ & $3.82 \pm 0.15 \mathrm{a}$ & $3.28 \pm 0.36 \mathrm{a}$ & $4.26 \pm 0.30 \mathrm{a}$ & $3.94 \pm 0.24 \mathrm{a}$ \\
SIL $(\mathrm{cm})$ & $112.8 \pm 5.66 \mathrm{a}$ & $103.2 \pm 4.81 \mathrm{a}$ & $97.0 \pm 5.03 \mathrm{a}$ & $125.8 \pm 5.38 \mathrm{~b}$ & $113.5 \pm 1.83 \mathrm{ab}$ \\
\hline
\end{tabular}

${ }^{*}$ Different letters in the same line indicate significant statistical difference $(P<0.05)$.

TABLE 3: Total cholesterol (TC), total protein (TP), globulin (GB), albumin (AL), triglycerides (TG), and glycemia (GL) in aging rats (C7, $\mathrm{C} 12$, and $\mathrm{C} 23$ groups) and aging rats supplemented with the aqueous extract of A. blazei (CA12 and CA23 groups). The results are expressed as mean \pm standard error.

\begin{tabular}{lccccc}
\hline & C7 & C12 & CA12 & C23 & CA23 \\
\hline TC (mg/dL) & $101.6 \pm 10.51 \mathrm{a}^{*}$ & $109.7 \pm 8.22 \mathrm{ab}$ & $125.1 \pm 13.37 \mathrm{ab}$ & $166 \pm 22.14 \mathrm{~b}$ & $140.3 \pm 17.08 \mathrm{ab}$ \\
TP $(\mathrm{g} / \mathrm{dL})$ & $6.04 \pm 0.15 \mathrm{a}$ & $7.03 \pm 0.14 \mathrm{~b}$ & $6.7 \pm 0.18 \mathrm{~b}$ & $6.9 \pm 0.10 \mathrm{~b}$ & $6.85 \pm 0.09 \mathrm{~b}$ \\
GB $(\mathrm{g} / \mathrm{dL})$ & $3.78 \pm 0.06 \mathrm{a}$ & $4.59 \pm 0.11 \mathrm{~b}$ & $4.43 \pm 0.17 \mathrm{~b}$ & $4.55 \pm 0.08 \mathrm{~b}$ & $4.42 \pm 0.14 \mathrm{~b}$ \\
AL $(\mathrm{g} / \mathrm{dL})$ & $2.27 \pm 0.16 \mathrm{a}$ & $2.43 \pm 0.08 \mathrm{a}$ & $2.27 \pm 0.09 \mathrm{a}$ & $2.35 \pm 0.07 \mathrm{a}$ & $2.42 \pm 0.04 \mathrm{a}$ \\
TG $(\mathrm{mg} / \mathrm{dL})$ & $135.4 \pm 11.99 \mathrm{a}$ & $147.4 \pm 15.79 \mathrm{a}$ & $146.2 \pm 15.2 \mathrm{a}$ & $166 \pm 33.09 \mathrm{a}$ & $145 \pm 34.85 \mathrm{a}$ \\
GL $(\mathrm{mg} / \mathrm{dL})$ & $124.5 \pm 2.95 \mathrm{a}$ & $111.8 \pm 6.56 \mathrm{a}$ & $120.1 \pm 4.06 \mathrm{a}$ & $132.3 \pm 7.16 \mathrm{a}$ & $150.8 \pm 6.8 \mathrm{~b}$ \\
\hline
\end{tabular}

${ }^{*}$ Different letters in the same line indicate significant statistical difference $(P<0.05)$.

and $100 \mathrm{~S}-100^{+}$glial cells per animal and $70 \mathrm{nNOS}^{+}$cell bodies per animal using ImagePro Plus 4.5 software (Media Cybernetics).

2.7. Statistical Analysis. The data were analyzed for normality using the Kolmogorov-Smirnov test. The parametric data were subjected to one-way analysis of variance (ANOVA) followed by Tukey's post hoc test using Prism 5.0 software (GraphPad, San Diego, CA, USA). The nonparametric data were analyzed using a block design with Statistica software (StatSoft) followed by Tukey's post hoc test. The significance level was 5\%, and the results are expressed as mean \pm standard error.

\section{Results}

3.1. Biometric Parameters. Body weight, food and water intake, the Lee index, periepididymal and retroperitoneal fat weight, and small intestine length are presented in Table 2.

3.2. Biochemical Analysis of Blood Components. The blood levels of total cholesterol, total proteins, globulins, albumin, triglycerides, and glycemia are shown in Table 3 . The plasma levels of the liver enzymes AST and ALT, which were evaluated at the beginning (C7) and end (C23 and CA23) of the experiment, were not significantly different between groups (Figure 1). The total antioxidant capacity of plasma (TAC-ABTS) was significantly reduced in 23-month-old animals. ABM supplementation did not significantly differ between the C23 and CA23 groups. A tendency $(P>0.05)$ toward an improvement in antioxidant capacity was observed in supplemented 12-month-old animals, but the difference between the C7 and C12 groups was not significant (Figure 2).

3.3. Histological Analysis. The intestinal morphometry results, MetI, and number of goblet cells are shown in Table 4.

3.4. Morphoquantitative Analysis of the Myenteric Plexus. Morphoquantitative changes were detected in $\mathrm{HuC} / \mathrm{HuD}^{+}$ myenteric neurons as a result of aging. Significant reductions of neuronal density and the number of neurons/ganglia (29.2\% and $32.4 \%$, resp.) were observed in the C23 group compared with the C7 group. Supplementation with the aqueous extract of $\mathrm{ABM}$ had a positive effect on $\mathrm{HuC} / \mathrm{HuD}^{+}$ myenteric neurons, in which the detected losses of density $(8.5 \%)$ and number of neurons/ganglia (17\%) in the C7 and CA23 groups were lower than in the 23-month-old control group. An increase in neuronal area $(P \leq 0.05)$ was observed in the $\mathrm{C} 12$ and $\mathrm{C} 23$ groups. The stable neuronal area in supplemented animals (CA12 and CA23 groups) compared with the C7 group indicates a neuroprotective effect of the ABM aqueous extract (Figure 3, Table 5).

The density of the subpopulation of nitrergic neurons $\left(\mathrm{nNOS}^{+}\right)$was preserved, regardless of age or supplementation. However, the neuronal profile of that population increased $(P \leq 0.05)$ with regard to age, with a positive effect of supplementation with the ABM aqueous extract at 12 months of age, with the exception of the CA23 group, in which the nitrergic neuron profile exhibited a significant reduction compared with the C7 and C23 groups (Figure 3). 
TABLE 4: Intestinal morphometry: total wall (TW), mucosa (MC), and muscle (MM) tunicae, villus height (VH), crypt depth (CD), metaphase index (MetI), and number of goblet cells (GLC) in the jejunum in aging rats (C7, C12, and $\mathrm{C} 23$ groups) and aging rats supplemented with the aqueous extract of $A$. blazei (CA12 and CA23 groups). The results are expressed as mean \pm standard error.

\begin{tabular}{lccccc}
\hline & C7 & C12 & CA12 & C23 & CA23 \\
\hline TW $(\mu \mathrm{m})$ & $835.13 \pm 1.97 \mathrm{a}^{*}$ & $760.65 \pm 2.32 \mathrm{~b}$ & $805.95 \pm 3.11 \mathrm{c}$ & $802.91 \pm 6.52 \mathrm{c}$ & $806.29 \pm 2.86 \mathrm{c}$ \\
MC $(\mu \mathrm{m})$ & $700.85 \pm 2.20 \mathrm{a}$ & $639.61 \pm 2.24 \mathrm{~b}$ & $674.99 \pm 3.24 \mathrm{c}$ & $648.92 \pm 5.56 \mathrm{~b}$ & $641.19 \pm 2.19 \mathrm{~b}$ \\
MM $(\mu \mathrm{m})$ & $100.8 \pm 0.59 \mathrm{a}$ & $101.1 \pm 0.89 \mathrm{a}$ & $98.61 \pm 0.67 \mathrm{a}$ & $103.2 \pm 0.82 \mathrm{a}$ & $113.9 \pm 1.13 \mathrm{~b}$ \\
VH $(\mu \mathrm{m})$ & $494.03 \pm 1.75 \mathrm{a}$ & $449.10 \pm 2.52 \mathrm{~b}$ & $464.42 \pm 2.36 \mathrm{c}$ & $458.05 \pm 3.23 \mathrm{c}$ & $420.02 \pm 2.91 \mathrm{~d}$ \\
CD $(\mu \mathrm{m})$ & $274.20 \pm 1.72 \mathrm{a}$ & $218.61 \pm 1.15 \mathrm{~b}$ & $212.31 \pm 1.14 \mathrm{c}$ & $244.00 \pm 1.56 \mathrm{~d}$ & $235.50 \pm 1.36 \mathrm{e}$ \\
MetI $(\%)$ & $7.59 \pm 0.35 \mathrm{a}$ & $6.78 \pm 0.57 \mathrm{a}$ & $6.74 \pm 0.34 \mathrm{a}$ & $7.42 \pm 0.52 \mathrm{a}$ & $7.53 \pm 0.32 \mathrm{a}$ \\
GLC $^{\#}$ & $72.09 \pm 2.49 \mathrm{a}$ & $75.34 \pm 2.99 \mathrm{a}$ & $74.48 \pm 2.59 \mathrm{a}$ & $53.07 \pm 1.88 \mathrm{~b}$ & $60.98 \pm 1.86 \mathrm{~b}$ \\
\hline
\end{tabular}

${ }^{*}$ Different letters in the same line indicate significant statistical difference $(P<0.05) .{ }^{*}$ Values expressed as goblet cells per field.

TABLE 5: Number of neurons $\left(\mathrm{HuC} / \mathrm{HuD}^{+}\right)$and glial cells $\left(\mathrm{S}_{100^{+}}\right)$per ganglion and glia/neuron ratio in rats at 7 months of age $(\mathrm{C} 7$ group) and 23 months of age (C23 group) and rats supplemented with the aqueous extract of A. blazei (CA23 group). The results are expressed as mean \pm standard error.

\begin{tabular}{lccc}
\hline & $\mathrm{C} 7$ & $\mathrm{C} 23$ & $\mathrm{CA} 23$ \\
\hline $\mathrm{HuC} / \mathrm{HuD}^{+} /$ganglion neurons & $24.84 \pm 0.74 \mathrm{a}^{*}$ & $16.77 \pm 0.50 \mathrm{~b}$ & $20.44 \pm 0.66 \mathrm{c}$ \\
$\mathrm{S} 100^{+} /$ganglion glias & $34.17 \pm 0.98 \mathrm{a}$ & $24.81 \pm 0.67 \mathrm{~b}$ & $29.37 \pm 0.90 \mathrm{c}$ \\
glias/neurons proportion & $1.37 \pm 0.03 \mathrm{a}$ & $1.50 \pm 0.12 \mathrm{a}$ & $1.44 \pm 0.07 \mathrm{a}$ \\
\hline
\end{tabular}

${ }^{*}$ Different letters in same line indicate significant statistical difference $(P<0.05)$.

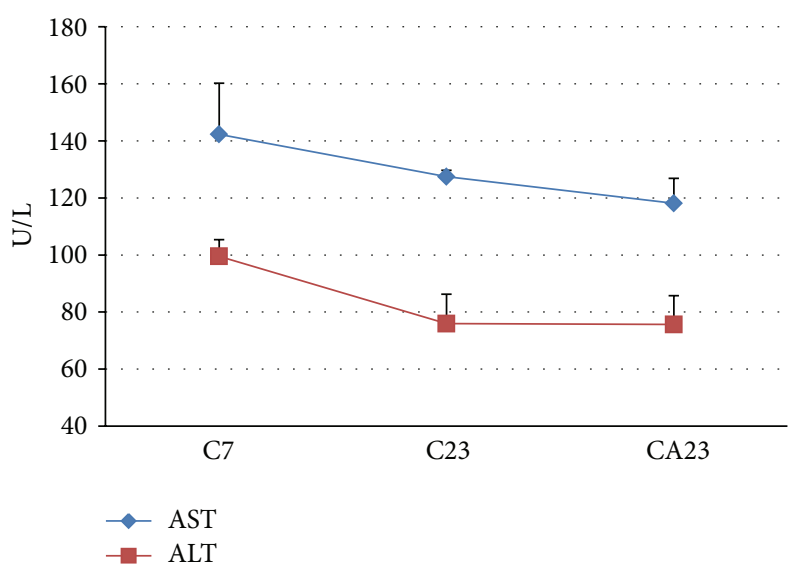

FIGURE 1: Plasma levels of the enzymes aspartate aminotransferase (AST) and alanine aminotransferase (ALT) in rats at 7 months of age (C7 group) and 23 months of age (C23 group) and 23-month-old rats supplemented with the aqueous extract of $A$. blazei (CA23 group). The results are expressed as mean \pm standard error.

The behavior of glial cells when comparing animals at 7 and 23 months of age revealed significant reductions of the density and number of glia of $26.3 \%$ and $27.3 \%$, respectively, and an increase in the glial cell profile $(P \leq 0.05)$. A positive effect of the ABM aqueous extract was observed, with a $9 \%$ reduction of glial density, $14 \%$ reduction of the number of glia, and maintenance of a similar glial profile as the 7-monthold animals (Figure 4, Table 5). The glia/neuron ratio was maintained among the analyzed groups (Table 5).

\section{Discussion}

4.1. Biometric Parameters. The concentration of the ABM aqueous extract lyophilized used for animal supplementation

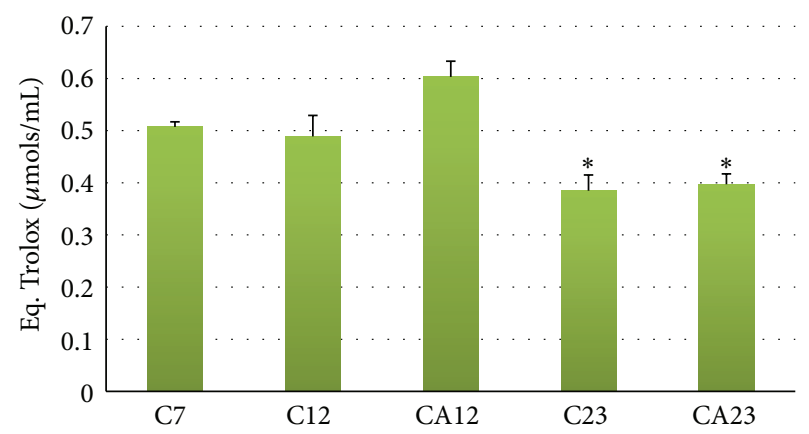

FIgURE 2: Total plasma antioxidant capacity (TAC-ABTS) in aging rats $(\mathrm{C} 7, \mathrm{C} 12$, and $\mathrm{C} 23$ groups) and aging rats supplemented with the aqueous extract of A. blazei (CA12 and CA23 groups). ${ }^{*} P<0.05$, compared with $\mathrm{C} 7$ group. The results are expressed as mean \pm standard error.

during the aging process was $26 \mathrm{mg} /$ animal/day (52 mg/kg). To standardize the supplementation dose, the commercial dosages ingested by humans were adopted as a reference, thus establishing a rate of intake of $4 \mathrm{~g}$ of dried mushrooms for a person who weighs approximately $60 \mathrm{~kg}$. Additionally, the concentration corresponds to one-quarter of the dosage of mushroom extract used in acute treatments $(200 \mathrm{mg} / \mathrm{kg})$ described for rats [23].

Throughout the experimental period, a reduction of food intake $(P<0.05)$ was observed beginning at 12 months of age compared with the 7-month-old group, with maintenance of body weight and water intake. The reduced food intake in 12 -month-old animals was $25 \%$, whereas the reduction for 23-month-old animals was $21 \%$ compared with 7-monthold animals. Raul et al. [10] reported that food intake decreases by approximately $20 \%$ in rats during the aging process. 


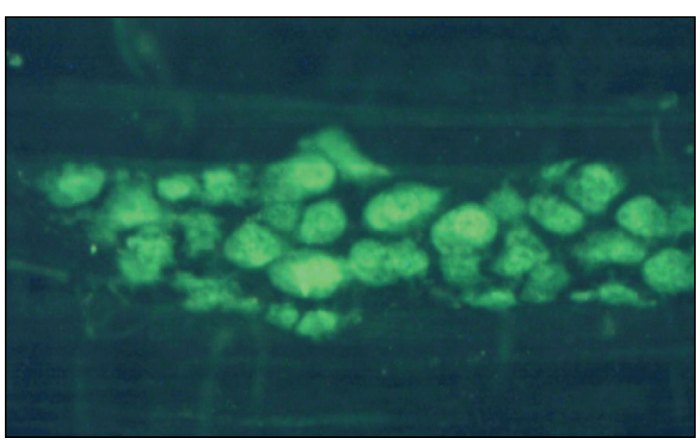

(a)
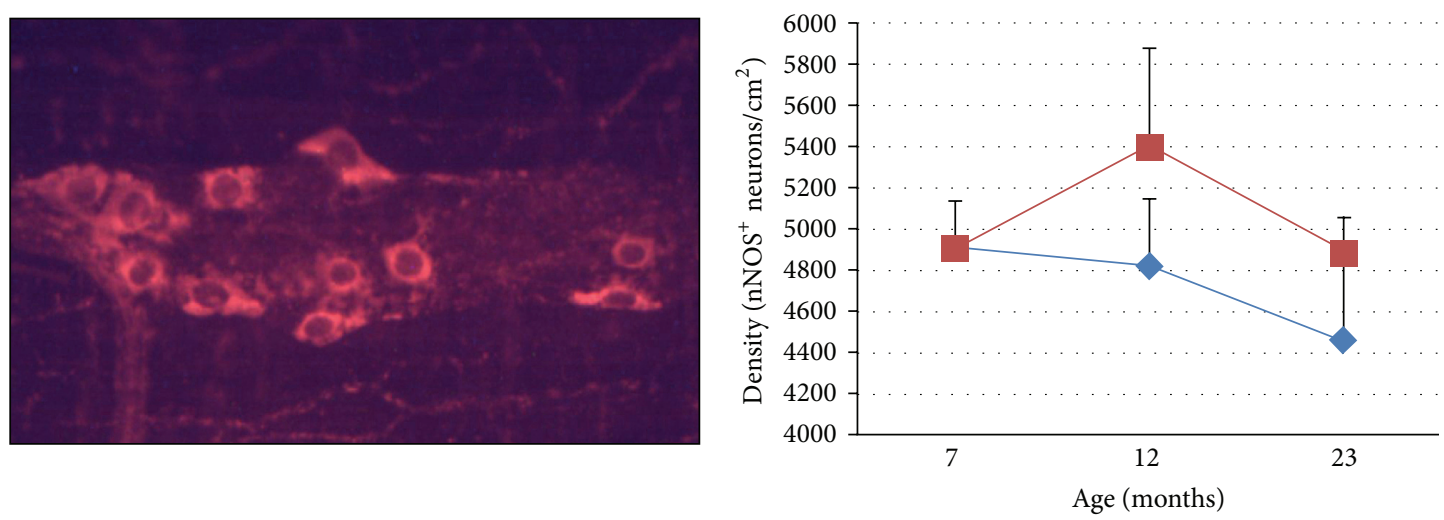

Aging

$\mathrm{ABM}$

(c)
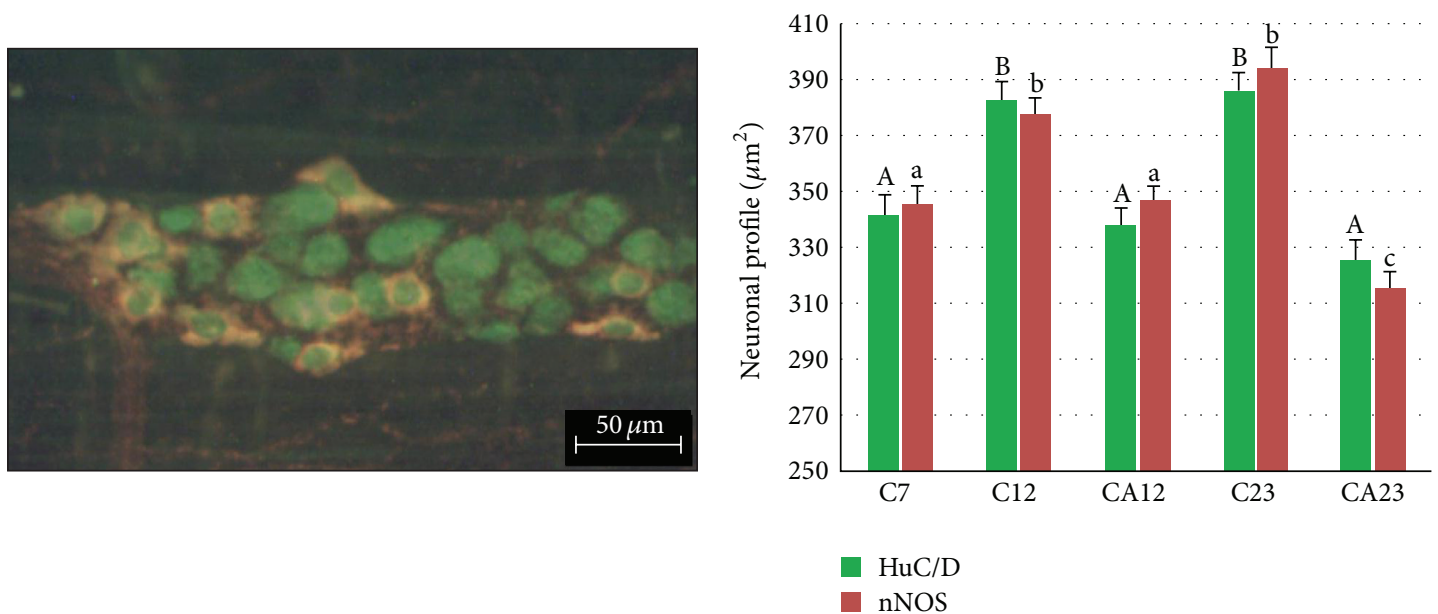

(e)

(f)

FIGURE 3: Myenteric ganglion of the jejunum in rats at 7 months of age: (a) HuC/ $\mathrm{D}^{+}$neurons and (c) nNOS ${ }^{+}$neurons. (e) Overlay of images from (a) and (c). Density of (b) $\mathrm{HuC} / \mathrm{D}^{+}$and (d) $\mathrm{nNOS}^{+}$myenteric neurons. Neuronal profile $\left(\mu \mathrm{m}^{2}\right)$ of HuC/D $\mathrm{D}^{+}$(green) and nNOS $(\mathrm{red})$ neurons shown in (f). Different letters in same-colored columns differ statistically (f). ${ }^{*} P<0.05$, compared with C7 group. AGING, C7, C12, and C23 groups; ABM, C7, CA12, and CA23 groups. The results are expressed as mean \pm standard error. Scale bar $=50 \mu \mathrm{m}$. 

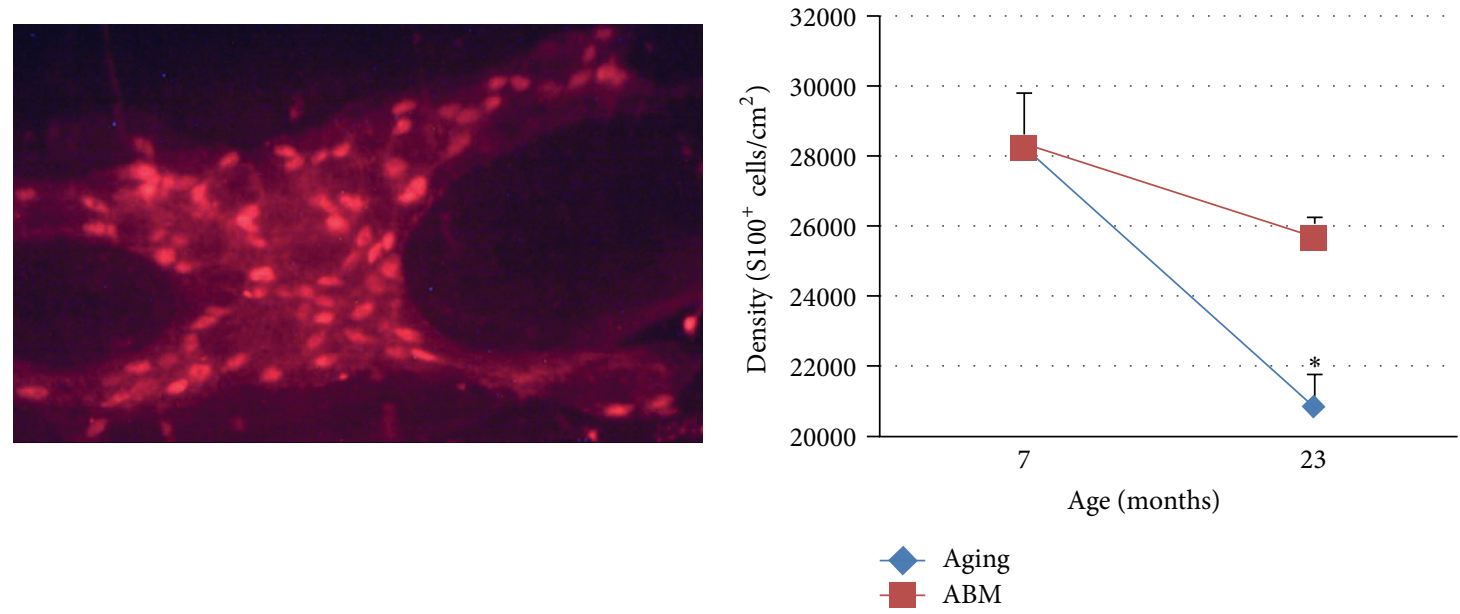

(a)

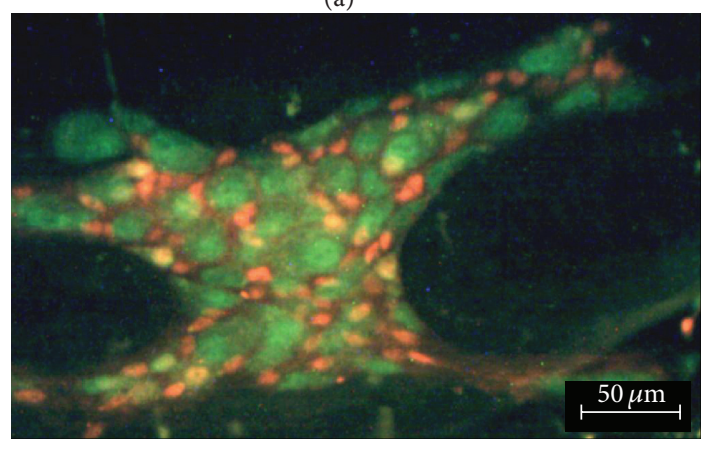

(c) (b)

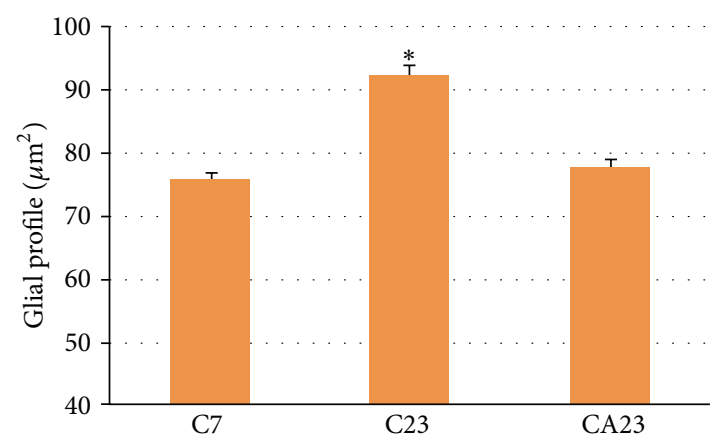

(d)

FIGURE 4: Myenteric ganglion of the jejunum in rats at 7 months of age: (a) $\mathrm{S}_{100^{+}}$glial cell body and (b) density of $\mathrm{S}_{00} 0^{+}$glial cells. $\mathrm{HuC}_{\mathrm{HuD}} \mathrm{Hu}^{+}$ and glial $\mathrm{S}_{100^{+}}$glial neuron cell bodies (c) and glial profile presented in (d). ${ }^{*} \mathrm{P}<0.05$, compared with C7 and CA23 groups. AGING, C7, and C23 groups; ABM, C7, and CA23 groups. The results are expressed as mean \pm standard error. Scale bar $=50 \mu \mathrm{m}$.

The association between final body weight and nasoanal length allows the calculation of the Lee index, a parameter comparable to body mass index. Together with the increase in retroperitoneal adipose tissue, the Lee index significantly increased in the C23 and CA23 groups compared with the C7 group, with no significant differences in periepididymal fat or total fat. The aging process in rats is associated with an increase in body fat [24] and decrease in muscle mass [25]. These changes mainly occur because of a decrease in basal metabolic rate and diminished physical activity $[26,27]$. We detected marked hypoactivity in the animals throughout the experiment and a significant reduction of food intake, which explain the stable body weight.

Age, regardless of supplementation, led to an increase in small intestine length in the C23 and CA23 groups. This increase may cause slower intestinal transit, with the possibility of constipation, a frequently reported symptom among the elderly [7]. Similar results were reported by Phillips et al. [28] and Johnson et al. [29], who observed a progressive increase in small intestine length at 24 months of age in Fischer 344 and Sprague Dawley rats, respectively. In Wistar rats, maintenance [10] and a reduction [8] of the size of the small intestine related to aging were found in 29- and 15-month-old animals, respectively.
Prolonged supplementation with the aqueous extract of $\mathrm{ABM}$ did not influence the analyzed biometric parameters, indicating that prolonged intake was responsible neither for the onset of being overweight or obesity nor for any stimulus toward greater feed or water intake. Notably, the Agaricus blazei mushroom is regarded as a highly nutritious food because of its carbohydrate, protein, and fiber content and low levels of fat [30].

4.2. Biochemical Analysis of Blood Components. Aging significantly increased $(P<0.05)$ total plasma cholesterol levels in 23 -month-old animals. This has been reported both for rats [31] and humans [32] in old age and is related to a higher incidence of diseases such as atherosclerosis [33].

One hypothesis for aging-related hypercholesterolemia involves the natural deficiency of growth hormone (GH) with aging. Parini et al. [31] reported a reduction of cholesterol in 18-month-old rats treated with $\mathrm{GH}$, which indicates the pleiotropic effects of this hormone on lipoprotein metabolism.

Considering that plasma low-density lipoprotein levels are determined by the balance between its synthesis and elimination, some authors have suggested an increase in the intestinal absorption of cholesterol with aging [34]. However, 
Gälman et al. [35] found that aging-related hypercholesterolemia in rats was attributable to reduced excretion and not to the higher intestinal absorption of cholesterol.

Supplementation with the ABM extract showed a marked tendency to reduce total cholesterol in 23-month-old animals, but this result was not statistically significant. The beneficial effects of an ethanolic extract of the Pleurotus ostreatus mushroom on cholesterol metabolism were observed in rats supplemented by gavage at a dose of $300 \mathrm{mg} / \mathrm{kg} /$ day [36]. A similar effect was observed with supplementation with $200 \mathrm{mg} / \mathrm{kg}$ of Agaricus bisporus in rats for 3 weeks [37]. In humans supplemented with Agaricus blazei for 3 months using a hot aqueous extract at a daily dose of $3 \mathrm{~g}$, Liu et al. [38] also reported a reduction of total cholesterol.

These results suggest a beneficial effect of mushrooms in reducing total cholesterol, but the form of extraction and daily dosage should be considered. We used a cold aqueous extract because it is safer with regard to the release of hepatotoxic substances previously described for extracts over $60^{\circ} \mathrm{C}$ [39]. We also supplemented animals with a low dosage administered over a prolonged period of time as a preventive measure and not as a treatment.

Aging also increased the serum levels of total proteins and globulins, but these levels are within the normal range for Wistar rats [40], with no influence of supplementation on these parameters. No effect of age or A. blazei supplementation on the blood levels of albumin or triglycerides was found.

Although glycemic levels are constant during the aging process, they were high $(P<0.05)$ in the CA23 group. The literature diverges with regard to glycemia in rodents, but we can discard the possible occurrence of a diabetic state because our values were less than $300 \mathrm{mg} / \mathrm{dL}$, the threshold value that indicates diabetes in Wistar rats [41].

Aging did not alter the plasma levels of AST and ALT, indicating that aging did not lead to liver damage as described for rats [42] and humans [43]. Moreover, prolonged supplementation with the ABM aqueous extract did not influence these enzymes, which demonstrates the reliability of the concentration administered daily to the animals over a prolonged period of time.

Lee et al. [44] supplemented Fischer 344 rats for 2 years with $A$. blazei aqueous extract and observed no carcinogenic effects in several organs, such as the liver, brain, lungs, and intestine. Antimutagenic effects of the ABM aqueous extract were reported by Barbisan et al. [45] prior to the chemical induction of cancer in rats, demonstrating protection in the initial stage of liver carcinogenesis but no effect when administered in the postinduction period. Previous studies have also shown that $A$. blazei exerts a protective effect on liver function in rats following injury induced by carbon tetrachloride $\left(\mathrm{CCl}_{4} ;[46]\right)$.

We observed a reduction of the total plasma antioxidant capacity (TAC-ABTS) in 23-month-old animals. The reduction of this capacity in animals in advanced age is frequently reported in the literature [47]. When analyzing the effect of $\mathrm{ABM}$ supplementation on this parameter, we observed a tendency toward improved plasma antioxidant capacity in 12-month-old supplemented animals, but no significant differences were found between the C23 and CA23 groups.
4.3. Histological Analysis. The classic histological organization of the jejunum was maintained in rats in all of the groups $[48,49]$. Nevertheless, morphometric alterations were detected in the aging process and with daily supplementation with the aqueous extract of Agaricus blazei. When analyzing the total intestinal wall, we observed a significant reduction of thickness in the 23-month-old animals; the same was observed for the mucosa tunic, villus height, and crypt depth in the intestine compared with 7-month-old rats (Table 3).

Reductions of the thickness of the intestinal wall and mucosa related to aging have been observed in rats $[9,10]$ and humans [50] as a consequence of the reduced food intake seen with aging, in which the availability of nutrients in the intestinal lumen demonstrably acts as a trophic factor [51].

According to Raul et al. [10], villus atrophy in Wistar rats between 12 and 29 months of age may be related to a decrease in the renewal rate of the epithelium, reflected by a corresponding reduction of crypt size. Höhn et al. [9] found villus atrophy of approximately $20-25 \%$ in 30-monthold rats, followed by architectural irregularity compared with 4-month-old rats.

Despite the reduction of these parameters, the cellular proliferation, reflected by the MetI, remained constant (Table 3). Equilibrium between cellular synthesis, migration, and extrusion processes leads to the maintenance of villus size and consequently the preservation of digestive and intestinal absorption capacity. Pluske et al. [52] highlighted that in situations of maintenance or reduction in the cell proliferation rate (MetI) associated with increased cell extrusion, in the apex of the villi, results in a reduction of their size. Our results indicate that absorption capacity was minimized and that supplementation with the ABM aqueous extract did not reverse this condition. The number of goblet cells per field was reduced $(P<0.05)$ with aging compared with the C7 group (Table 3), which is consistent with the reductions of villi and crypts discussed previously. Valenkevich and Zhukova [50] reported similar results for goblet cells in the duodenum in advanced-age humans. Caliciform cells are involved in the production of mucus that protects and lubricates the surface of the intestinal epithelium; therefore, reduced mucus secretion in response to aging [53] can damage the intestine by reducing the protective barrier against pathogens, facilitating their transport toward the inside of the mucosa and increasing the susceptibility to infection [51]. Fasting or dietary changes can also result in a reduction of the protective mucus layer [51].

Supplementation with the aqueous extract of $A$. blazei showed a tendency toward alleviating this condition in the CA23 group, but no significant differences were detected compared with the C23 group. This improvement may be explained by considering that the aqueous extract provided protein supplementation in the diet.

The muscular coat did not exhibit significant differences in thickness during the aging process (Figure 1). This result is consistent with Marese et al. [8], who attributed this result to a normal developmental condition imposed on the animal by diets with a normal protein content, regardless of age, although a reduction of intestinal motility associated with age was reported [53]. 
Supplementation with the ABM aqueous extract increased the muscular coat in old supplemented animals (CA23 group) compared with nonsupplemented animals (C23). The amount of proteins and amino acids present in the $\mathrm{ABM}$ aqueous extract $[54,55]$ likely contributed to the increase in the muscular coat during the long period of supplementation. Low-protein diets have been shown to reduce muscular coat thickness in Wistar rats [56].

4.4. Morphoquantitative Analysis of the Myenteric Plexus. We found that the density and number of cells per ganglion in the myenteric neuron $\left(\mathrm{HuC} / \mathrm{D}^{+}\right)$and glial cell $\left(\mathrm{S}_{100^{+}}\right)$population were significantly reduced at 7 and 23 months of age, whereas the density of the nitrergic subpopulation $\left(\mathrm{nNOS}^{+}\right)$remained stable.

Quantitative reductions of the enteric neuron population are frequently reported in the literature and may be linked to gastrointestinal problems, such as dysphagia, gastroesophageal reflux disorders, diarrhea, constipation, and fecal incontinence [57]. In addition to alterations in the ENS, damage to the sympathetic innervation of the plexi may be a possible mechanism for the decline in gastrointestinal motor function seen in old rats [58].

Reduction of the number of neurons has been observed in humans [59], guinea pigs [60], and rats $[61,62]$ in both the small intestine $[8,21,28]$ and large intestine $[21,28]$. The latter is seen as the most susceptible to aging-associated damage. In addition to effects in different species, organs, and segments, neuron populations and subpopulations can be affected differently.

Nitrergic neurons synthesize nitric oxide through nitric oxide synthase, and cholinergic neurons synthesize acetylcholine through choline acetyltransferase. These two neuronal subpopulations combined represent almost the entire myenteric neuron population in rats [63]. Phillips et al. [28] compared 3- and 24-month-old rats and found that neuronal loss in the small and large intestines occurred only with cholinergic neurons, thus corroborating the data obtained in the present study. Neurons marked by the pan neuronal marker anti-HuC/D in the cytoskeleton [64] were reduced by $29.2 \%$ in 23 -month-old animals compared with the C7 group. The density of the nitrergic subpopulation was not significantly reduced, supporting the hypothesis that certain neuron classes may be more susceptible to aging than others $[61,65]$.

The cell profile analysis showed that the aging process significantly increased the cell body area for both $\mathrm{HuC} / \mathrm{HuD}^{+}$ and $\mathrm{nNOS}^{+}$neurons beginning at 12 months of age, although no quantitative alterations were detected during that period, which remained unchanged until 23 months of age. Agerelated neuronal cell body hypertrophy was also described by Marese et al. [8] and Schoffen and Natali [14], who compared the duodenum in 3- and 14-month-old Wistar rats and the proximal colon in 3- and 12-month-old Wistar rats, respectively. This was considered a neuronal adaptation attributable to the reduced number of neurons.

Notably, despite maintaining their density, the changes in the cell profile of nitrergic neurons indicated that they were completely spared from the effects of aging. Phillips et al.
[28] used the NADPH-diaphoresis technique and observed an increase in the cell body area of nitrergic neurons in the colon and rectum in 24-month-old Fischer 344 rats, with no alterations in the small intestine. These data differ from the results obtained in the present study.

The ENS changes that occur with aging may be related to a reduction of neurotrophic factors secreted by glial cells, which are important in neuronal development and maintenance [13]. In our work, glial loss was proportional to myenteric neuronal death. The glia:neuron ratio did not change over the different ages studied. The same pattern of cellular death was observed by Phillips et al. [21], who performed double-HuC/HuD-S100 immunostaining in Fischer 344 rats at 6 and 26 months of age, suggesting the interdependence of these two cell types.

The glial profile was also altered as a consequence of aging. An increase was observed in the mean cell body area in 23-month-old rats compared with 7-month-old rats. The progressive hypertrophy of astrocytes immunolabeled by the S-100 protein in the central nervous system also occurs frequently during the aging process in rats [66]. However, that population in the enteric nervous system has been seldom evaluated.

The quantitative reduction of cells present in enteric ganglia may be directly related to oxidative stress because of the higher production of free radicals and a decrease in the activity of antioxidant enzymes [1] that occurs during the aging process. Thrasivoulou et al. [12] performed in vitro analyses of myenteric neurons in Sprague-Dawley rats and found that the start of cellular death is linked to higher intraneuronal levels of reactive oxygen species (ROS).

Given that the total plasma antioxidant capacity (TAC) was reduced in 23-month-old rats and that the $\mathrm{ABM}$ aqueous extract has demonstrable antioxidant potential [55], we infer that the extract efficiently preserved neurons and glia in the myenteric plexus in old animals. No differences were detected in the number or profile of the cell bodies of glial cells and myenteric $\mathrm{HuC} / \mathrm{D}$ neurons ${ }^{+}$in the supplemented groups (CA12 and CA23) compared with the 7-month-old group.

Despite the numeric maintenance of nitrergic neurons during aging, atrophy was detected in the middle area of cell bodies in that neuronal subpopulation in 23-monthold supplemented animals compared with the 7-month-old group.

The possible involvement of specific components of the $\mathrm{ABM}$ aqueous extract, such as polyphenols, might justify this reduction because of their reported ability to sequester nitric oxide in vitro [67] and in vivo [68]. van Acker et al. [67] reported the neuroprotective effects of polyphenols. Epigallocatechin, a polyphenol isolated from green tea administered intraperitoneally in rats, attenuated oxidative stress by reducing the expression of nNOS and NADPH-d in parasympathetic ganglion neurons that extrinsically innervate the digestive tube in rats following hypoxia.

The precise mechanism by which $A$. blazei prevents neuronal death is still unclear. Nevertheless, considering that neuronal death can be a consequence of glial death [69], we can infer that the functions of glial cells were preserved by 
prolonged intake of the $\mathrm{ABM}$ aqueous extract during the aging process.

One hypothesis is that antioxidant compounds contained in the ABM aqueous extract have direct actions on free radicals generated in enteric glial cells. Given that they are similar to central nervous system (CNS) astrocytes with regard to their morphological and immunohistochemical characteristics [70, 71], this hypothesis can be supported by the results obtained by Sharma et al. [72], which indicate a positive effect of flavonoids on astrocytes through the modulation of glial fibrillary acidic protein (GFAP) and glutamine synthetase, with involvement in protective events, reducing apoptosis in a neuronal culture. Another hypothesis is that the chronic intake of glutamic acid (or glutamate) found in the aqueous extract of $A$. blazei has indirect antioxidant effects $[54,73]$. Glutamic acid can be converted into glutamine, a precursor of glutathione, one of the most powerful cellular antioxidants. This substance is produced and released by enteric glial cells for neuronal preservation in cases of oxidative stress [74]. Moreover, Muyderman et al. [75] demonstrated that mitochondrial glutathione is essential for preserving the viability of astrocytes in the SNC during conditions of increased levels of free radicals, which supports our hypothesis.

A positive relationship between antioxidant compound supplementation and enteric neuroprotection in diabetic neuropathy has been reported by several authors. This diabetic condition, similar to aging, is associated with oxidative stress as one of its main degenerative factors [3]. Among the supplements studied in experimental models of diabetic neuropathy are ascorbic acid [76], $\alpha$-tocopherol [77], Lglutamine [78], Ginkgo biloba [79], and quercetin [80].

In aging, a neuroprotective effect was detected in the ENS in the small intestine [81] and large intestine [82] in rats supplemented with Ginkgo biloba extract. Similarly, [83] found that supplementation with ascorbic acid had a neurotrophic effect on myenteric neurons in old rats, suggesting neuroprotection.

\section{Conclusions}

Aging modifies biometric, blood, and morphofunctional parameters in the jejunum and causes morphoquantitative changes in the enteric nervous system. Prolonged supplementation with the aqueous extract of Agaricus blazei efficiently maintained myenteric plexus homeostasis, which positively influenced the physiology and prevented the death of the neurons and glial cells.

\section{Conflict of Interests}

The authors declare that there is no conflict of interests regarding the publication of this paper.

\section{Acknowledgments}

This work was supported by grants from Conselho Nacional de Desenvolvimento Científico e Tecnológico (CNPq) and Fundação Araucária, PR, Brazil.

\section{References}

[1] L. Tiana, Q. Caib, and H. Wei, "Alterations of antioxidant enzymes and oxidative damage to macromolecules in different organs of rats during aging," Free Radical Biology \& Medicine, vol. 24, no. 9, pp. 1477-1484, 1998.

[2] T. A. Prolla and M. P. Mattson, "Molecular mechanisms of brain aging and neurodegenerative disorders: lessons from dietary restriction," Trends in Neurosciences, vol. 24, pp. 21-31, 2001.

[3] A. M. Vincent, J. W. Russell, P. Low, and E. L. Feldman, "Oxidative stress in the pathogenesis of diabetic neuropathy," Endocrine Reviews, vol. 25, no. 4, pp. 612-628, 2004.

[4] H. Imai and Y. Nakagawa, "Biological significance of phospholipid hydroperoxide glutathione peroxidase (PHGPx, GPx4) in mammalian cells," Free Radical Biology \& Medicine, vol. 34, no. 2, pp. 145-169, 2003.

[5] T. Takaku, Y. Kimura, and H. Okuda, "Isolation of an antitumor compound from Agaricus blazei Murill and its mechanism of action," Journal of Nutrition, vol. 131, no. 5, pp. 1409-1413, 2001.

[6] K. E. Hall, "Aging and neural control of the GI tract II. Neural control of the aging gut: can an old dog learn new tricks?" The American Journal of Physiology-Gastrointestinal and Liver Physiology, vol. 283, no. 4, pp. 827-832, 2002.

[7] P. R. Wade, "Aging and neural control of the GI tract I. Agerelated changes in the enteric nervous system," The American Journal of Physiology-Gastrointestinal and Liver Physiology, vol. 283, no. 3, pp. G489-G495, 2002.

[8] A. C. M. Marese, P. de Freitas, and M. R. M. Natali, "Alterations of the number and the profile of myenteric neurons of Wistar rats promoted by age," Autonomic Neuroscience: Basic \& Clinical, vol. 137, no. 1-2, pp. 10-18, 2007.

[9] P. Höhn, H. Gabbert, and R. Wagner, "Differentiation and aging of the rat intestinal mucosa. II. Morphological, enzyme histochemical and disc electrophoretic aspects of the aging of the small intestinal mucosa," Mechanisms of Ageing and Development, vol. 7, no. 3, pp. 217-226, 1978.

[10] F. Raul, F. Gosse, M. Doffoel, P. Darmenton, and J. Y. Wessely, "Age related increase of brush border enzyme activities along the small intestine," Gut, vol. 29, no. 11, pp. 1557-1563, 1988.

[11] J. B. Furness, M. Costa, A. Rökaeus, T. J. McDonald, and B. Brooks, "Galanin-immunoreactive neurons in the guinea-pig small intestine: their projections and relationships to other enteric neurons," Cell and Tissue Research, vol. 250, pp. 607-615, 1987.

[12] C. Thrasivoulou, H. Ridha, V. Soubeyre, C. H. V. Hoyle, M. J. Saffrey, and T. Cowen, "Free radical buffering in rat enteric neurons: effects of age and neurotrhophic factors," European Journal of Neuroscience, vol. 12, p. 33, 2000.

[13] N. F. Dolatshad, A. T. Silva, V. Soubeyre, C. H. V. Hoyle, T. Cowen, and M. J. Saffrey, "Expression of the GNDF and its receptors in the ageing gut," Soc Neurosci Abtsr 27:861-864, 2001.

[14] J. P. F. Schoffen and M. R. M. Natali, "Effect of age on the myosin-V immunoreactive myenteric neurons of rats ileum," Biocell, vol. 31, no. 1, pp. 33-39, 2007.

[15] A. A. Soares, C. G. M. de Souza, F. M. Daniel, G. P. Ferrari, S. M. G. da Costa, and R. M. Peralta, "Antioxidant activity and total phenolic content of Agaricus brasiliensis (Agaricus blazei Murril) in two stages of maturity," Food Chemistry, vol. 112, no. 4, pp. 775-781, 2009.

[16] A. A. Soares, Efeitos do cogumelo Agaricus brazei Murrill sobre os danos causados pelo paracetamol aos tecidos hepático e cerebral 
de ratos [Ph. D. thesis], University of Maringa, Maringá, Brazil, 2013.

[17] O. Erel, "A novel automated direct measurement method for total antioxidant capacity using a new generation, more stable ABTS radical cation," Clinical Biochemistry, vol. 37, no. 4, pp. 277-285, 2004.

[18] I. F. Tannock, "A comparison of the relative efficiencies of various metaphase arrest agents," Experimental Cell Research, vol. 47, no. 1-2, pp. 345-356, 1967.

[19] Z. Lin, N. Gao, H.-Z. Hu et al., "Immunoreactivity of $\mathrm{Hu}$ proteins facilitates identification of myenteric neurones in guinea-pig small intestine," Neurogastroenterology \& Motility, vol. 14, no. 2, pp. 197-204, 2002.

[20] H. F. Wrzos, A. Cruz, R. Polavarapu, D. Shearer, and A. Ouyang, "Nitric oxide synthase (NOS) expression in the myenteric plexus of streptozotocin-diabetic rats," Digestive Diseases and Sciences, vol. 42, no. 10, pp. 2106-2110, 1997.

[21] R. J. Phillips, E. J. Kieffer, and T. L. Powley, "Loss of glia and neurons in the myenteric plexus of the aged Fischer 344 rat," Anatomy and Embryology, vol. 209, no. 1, pp. 19-30, 2004.

[22] D. M. G. Sant'ana, M. H. de Miranda-Neto, R. R. de Souza, and S. L. Molinari, "Morphological and quantitative study of the myenteric plexus of the ascending colon of rats subjected to proteic desnutrition," Arquivos de Neuro-Psiquiatria, vol. 55, no. 4, pp. 687-695, 1997.

[23] T. Jayakumar, P. Aloysius Thomas, and P. Geraldine, "Protective effect of an extract of the oyster mushroom, Pleurotus ostreatus, on antioxidants of major organs of aged rats," Experimental Gerontology, vol. 42, no. 3, pp. 183-191, 2007.

[24] A. Gommers, M. Dehez-Delhaye, and D. J. Caucheteux, "Morphological and metabolic alterations in adipose tissue of very old rats," Journals of Gerontology, vol. 38, no. 6, pp. 666-672, 1983.

[25] M. R. Caccia, J. B. Harris, and M. A. Johnson, "Morphology and physiology of skeletal muscle in aging rodents," Muscle and Nerve, vol. 2, no. 3, pp. 202-212, 1979.

[26] E. Perissinotto, C. Pisent, G. Sergi, F. Grigoletto, and G. Enzi, "Anthropometric measurements in the elderly: age and gender differences," The British Journal of Nutrition, vol. 87, no. 2, pp. 177-186, 2002.

[27] B. Steen, "Body composition and aging.", Nutrition Reviews, vol. 46, no. 2, pp. 45-51, 1988.

[28] R. J. Phillips, E. J. Kieffer, and T. L. Powley, "Aging of the myenteric plexus: neuronal loss is specific to cholinergic neurons," Autonomic Neuroscience: Basic and Clinical, vol. 106, no. 2, pp. 69-83, 2003.

[29] R. J. R. Johnson, M. Schemann, R. M. Santer, and T. Cowen, "The effects of age on the overall population and on subpopulations of myenteric neurons in the rat small intestine," Journal of Anatomy, vol. 192, no. 4, pp. 479-488, 1998.

[30] M. R. C. G. Novaes, "Cogumelos comestíveis da ordem Agaricales: Aspectos nutricionais e atividade farmacológica no câncer," Infarma, vol. 19, pp. 147-150, 2007.

[31] P. Parini, B. Angelin, and M. Rudling, "Cholesterol and lipoprotein metabolism in aging: reversal of hypercholesterolemia by growth hormone treatment in old rats," Arteriosclerosis, Thrombosis, and Vascular Biology, vol. 19, no. 4, pp. 832-839, 1999.

[32] R. A. Kreisberg and S. Kasim, "Cholesterol metabolism and aging," The American Journal of Medicine, vol. 82, no. 1, supplement 2, pp. 54-60, 1987.
[33] A. Ledwoż;yw, J. Michalak, A. Stępień, and A. Ką̧dziołka, "The relationship between plasma triglycerides, cholesterol, total lipids and lipid peroxidation products during human atherosclerosis," Clinica Chimica Acta, vol. 155, no. 3, pp. 275283, 1986.

[34] D. Q.-H. Wang, "Aging per se is an independent risk factor for cholesterol gallstone formation in gallstone susceptible mice," The Journal of Lipid Research, vol. 43, no. 11, pp. 1950-1959, 2002.

[35] C. Gälman, M. Matasconi, L. Persson, P. Parini, B. Angelin, and M. Rudling, "Age-induced hypercholesterolemia in the rat relates to reduced elimination but not increased intestinal absorption of cholesterol," The American Journal of PhysiologyEndocrinology and Metabolism, vol. 293, no. 3, pp. E737-E742, 2007.

[36] M. G. Ahmed, E. Y. Heba, and H. I. Hala, "Protective effects of mushroom and their ethyl extract on aging rats compared with L-carnitine," Nature, vol. 8, no. 10, 2010.

[37] S. C. Jeonga, Y. T. Jeongb, and B. K. Yangb, "White button mushroom (Agaricus bisporus) lowers blood glucose and cholesterol levels in diabetic and hypercholesterolemic rats," Nutrition Research, vol. 30, pp. 49-56, 2010.

[38] Y. Liu, Y. Fukuwatari, K. Okumura et al., "Immunomodulating activity of Agaricus brasiliensis KA21 in mice and in human volunteers," Evidence-Based Complementary and Alternative Medicine, vol. 5, no. 2, pp. 205-219, 2008.

[39] A. F. Eira, Cultivo do cogumelo medicinal Agaricus blazei (Murril) ss. Heinemann ou Agaricus brasiliensis (Wasser et al.), Aprenda Fácil, Viçosa, Brazil, 2003.

[40] E. V. Hillyer and K. E. Quesenberry, Ferrets, Rabbits and Rodents Clinical Medicine and Sugery, Saunders, London, UK, 1997.

[41] W. Liu, W. Yue, and R. Wu, "Effects of diabetes on expression of glial fibrillary acidic protein and neurotrophins in rat colon," Autonomic Neuroscience: Basic \& Clinical, vol. 154, no. 1-2, pp. 79-83, 2010.

[42] L. E. Rikans, "Influence of aging on the susceptibility of rats to hepatotoxic injury," Toxicology and Applied Pharmacology, vol. 73, no. 2, pp. 243-249, 1984.

[43] I. P. B. Moreira, L. E. B. Amado, A. L. F. Bersani, C. A. BersaniAmado, and S. M. Caparroz-Assef, "Principais aspectos do tratamento das infecções no idoso," Ciência, Cuidado e Saúde, vol. 6, pp. 488-495, 2007.

[44] Y.-L. Lee, S.-Y. Jian, P.-Y. Lian, and J.-L. Mau, "Antioxidant properties of extracts from a white mutant of the mushroom Hypsizigus marmoreus," Journal of Food Composition and Analysis, vol. 21, no. 2, pp. 116-124, 2008.

[45] L. F. Barbisan, M. Miyamoto, C. Scolastici et al., "Influence of aqueous extract of Agaricus blazei on rat liver toxicity induced by different doses of diethylnitrosamine," Journal of Ethnopharmacology, vol. 83, no. 1-2, pp. 25-32, 2002.

[46] A. M. Al-Dbass, S. K. Al- Daihan, and R. S. Bhat, "Agaricus blazei Murill as an efficient hepatoprotective and antioxidant agent against CCl4-induced liver injury in rats," Saudi Journal of Biological Sciences, vol. 19, no. 3, pp. 303-309, 2012.

[47] J. L. Quiles, J. J. Ochoa, M. Battino et al., "Life-long supplementation with a low dosage of coenzyme Q10 in the rat: effects on antioxidant status and DNA damage," BioFactors, vol. 25, no. 14, pp. 73-86, 2005.

[48] W. B. Gartner and J. L. Hiat, Tratado de Histologia em cores, Elsevier, Rio de Janeiro, Brazil, 2007.

[49] F. Moog, "The small intestine in old mice: growth, alkaline phosphatase and disaccharidase activities, and deposition of 
amyloid," Experimental Gerontology, vol. 12, no. 5-6, pp. 223235, 1977.

[50] I. N. Valenkevich and N. M. Zhukova, "The structure of the mucous membrane of the human duodenum with aging," Arkhiv Patologii, vol. 38, pp. 58-61, 1976.

[51] M. Macari, R. L. Furlan, and E. Gonzales, Fisiologia aviária aplicada a frangos de corte, São Paulo, Brazil, Funep, 2002.

[52] J. R. Pluske, D. J. Hampson, and I. H. Williams, "Factors influencing the structure and function of the small intestine in the weaned pig: a review," Livestock Production Science, vol. 51, no. 1-3, pp. 215-236, 1997.

[53] J. M. Mullin, M. C. Valenzano, J. J. Verrecchio, and R. Kothari, "Age- and diet-related increase in transepithelial colon permeability of Fischer 344 rats," Digestive Diseases and Sciences, vol. 47, no. 10, pp. 2262-2270, 2002.

[54] M.-Y. Kim, L.-M. Chung, S.-J. Lee et al., "Comparison of free amino acid, carbohydrates concentrations in Korean edible and medicinal mushrooms," Food Chemistry, vol. 113, no. 2, pp. 386393, 2009.

[55] A. A. Soares, A. B. Sá-Nakanishi, A. L. Oliveira et al., "Effects of the aqueous estract of Agaricus blazei (Murrill) on the hepatic glycogen and lipids contents in rats submitted to injury by paracetamol," in XLI Annual Meeting of SBBq, 2012.

[56] M. R. M. Natali, S. L. Molinari, L. C. Valentini, and M. H. de Miranda Neto, "Morphoquantitative evaluation of the duodenal myenteric neuronal population in rats fed with hypoproteic ration," Biocell, vol. 29, no. 1, pp. 39-46, 2005.

[57] P. R. Wade and T. Cowen, "Neurodegeneration: a key factor in the ageing gut," Neurogastroenterology and Motility, vol. 16, no. 1, pp. 19-23, 2004.

[58] R. J. Phillips, B. S. Rhodes, and T. L. Powley, "Effects of age on sympathetic innervation of the myenteric plexus and gastrointestinal smooth muscle of Fischer 344 rats," Anatomy and Embryology, vol. 211, no. 6, pp. 673-683, 2006.

[59] O. A. Gomes, R. R. de Souza, and E. A. Liberti, "A preliminary investigation of the effects of aging on the nerve cell number in the myenteric ganglia of the human colon," Gerontology, vol. 43, no. 4, pp. 210-217, 1997.

[60] G. Gabella, "Fall in the number of myenteric neurons in aging guinea pigs," Gastroenterology, vol. 96, no. 6, pp. 1487-1493, 1989.

[61] T. Cowen, R. J. R. Johnson, V. Soubeyre, and R. M. Santer, "Restricted diet rescues rat enteric motor neurones from age related cell death," Gut, vol. 47, no. 5, pp. 653-660, 2000.

[62] J. P. F. Schoffen, A. Soares, P. de Freitas, N. C. Buttow, and M. R. M. Natali, "Effects of a hypoproteic diet on myosin-V immunostained myenteric neurons and the proximal colon wall of aging rats," Autonomic Neuroscience: Basic \& Clinical, vol. 122, no. 1-2, pp. 77-83, 2005.

[63] K. Nakajima, I. Tooyama, O. Yasuhara, Y. Aimi, and H. Kimura, "Immunohistochemical demonstration of choline acetyltransferase of a peripheral type (pChAT) in the enteric nervous system of rats," Journal of Chemical Neuroanatomy, vol. 18, no. 1-2, pp. 31-40, 2000.

[64] R. J. Phillips, S. L. Hargrave, B. S. Rhodes, D. A. Zopf, and T. L. Powley, "Quantification of neurons in the myenteric plexus: an evaluation of putative pan-neuronal markers," Journal of Neuroscience Methods, vol. 133, no. 1-2, pp. 99-107, 2004.

[65] C. E. Bernard, S. J. Gibbons, P. J. Gomez-Pinilla et al., "Effect of age on the enteric nervous system of the human colon," Neurogastroenterology \& Motility, vol. 21, no. 7, p. 746-e4, 2009.
[66] M. Sabbatini, P. Barili, E. Bronzetti, D. Zaccheo, and F. Amenta, "Age-related changes of glial fibrillary acidic protein immunoreactive astrocytes in the rat cerebellar cortex," Mechanisms of Ageing and Development, vol. 108, no. 2, pp. 165-172, 1999.

[67] S. A. B. E. van Acker, M. N. J. L. Tromp, G. R. M. M. Haenen, W. J. F. van der Vijgh, and A. Bast, "Flavonoids as scavengers of nitric oxide radical," Biochemical and Biophysical Research Communications, vol. 214, no. 3, pp. 755-759, 1995.

[68] I.-H. Wei, Y.-C. Wu, C.-Y. Wen, and J.-Y. Shieh, "Green tea polyphenol (-)-epigallocatechin gallate attenuates the neuronal $\mathrm{NADPH}-\mathrm{d} / \mathrm{nNOS}$ expression in the nodose ganglion of acute hypoxic rats," Brain Research, vol. 999, no. 1, pp. 73-80, 2004.

[69] R. J. Phillips and T. L. Powley, "Innervation of the gastrointestinal tract: Patterns of aging," Autonomic Neuroscience: Basic and Clinical, vol. 136, no. 1-2, pp. 1-19, 2007.

[70] G. L. Ferri, L. Probert, D. Cocchia, F. Michetti, P. J. Marangos, and J. M. Polak, "Evidence for the presence of S-100 protein in the glial component of the human enteric nervous system," Nature, vol. 297, no. 5865, pp. 409-410, 1982.

[71] K. R. Jessen, R. Thorpe, and R. Mirsky, "Molecular identity, distribution and heterogeneity of glial fibrillary acidic protein: an immunoblotting and immunohistochemical study of Schwann cells, satellite cells, enteric glia and astrocytes," Journal of Neurocytology, vol. 13, no. 2, pp. 187-200, 1984.

[72] V. Sharma, M. Mishra, S. Ghosh et al., "Modulation of interleukin $-1 \beta$ mediated inflammatory response in human astrocytes by flavonoids: implications in neuroprotection," Brain Research Bulletin, vol. 73, no. 1-3, pp. 55-63, 2007.

[73] J. H. Hong, K. S. Youn, and Y. H. Choi, "Characteristics of crude protein-bound polysaccharide from Agaricus blazei Murill by extraction and precipitation conditions and its antitumor effect," Korean Journal of Food Science and Technology, vol. 36, pp. 586-593, 2004.

[74] H. Abdo, P. Derkinderen, P. Gomes et al., "Enteric glial cells protect neurons from oxidative stress in part via reduced glutathione," The FASEB Journal, vol. 24, no. 4, pp. 1082-1094, 2010.

[75] H. Muyderman, A. L. Wadey, M. Nilsson, and N. R. Sims, "Mitochondrial glutathione protects against cell death induced by oxidative and nitrative stress in astrocytes," Journal of Neurochemistry, vol. 102, no. 4, pp. 1369-1382, 2007.

[76] P. de Freitas, M. R. M. Natali, R. V. F. Pereira, M. H. M. Neto, and J. N. Zanoni, "Myenteric neurons and intestinal mucosa of diabetic rats after ascorbic acid supplementation," World Journal of Gastroenterology, vol. 14, no. 42, pp. 6518-6524, 2008.

[77] L. P. Roldi, R. V. F. Pereira, E. A. Tronchini et al., "Vitamin E ( $\alpha$-tocopherol) supplementation in diabetic rats: effects on the proximal colon," BMC Gastroenterology, vol. 9, article 88, 2009.

[78] R. V. F. Pereira, E. A. Tronchini, C. M. Tashima, E. P. B. Alves, M. M. Lima, and J. N. Zanoni, "L-glutamine supplementation prevents myenteric neuron loss and has gliatrophic effects in the ileum of diabetic rats," Digestive Diseases and Sciences, vol. 56, no. 12, pp. 3507-3516, 2011.

[79] G. G. P. da Silva, J. N. Zanoni, and N. C. Buttow, "Neuroprotective action of Ginkgo biloba on the enteric nervous system of diabetic rats," World Journal of Gastroenterology, vol. 17, no. 7, pp. 898-905, 2011.

[80] C. R. P. Lopes, P. E. B. Ferreira, J. N. Zanoni, A. M. P. Alves, E. P. B. Alves, and N. C. Buttow, "Neuroprotective effect of quercetin on the duodenum enteric nervous system of streptozotocininduced diabetic rats," Digestive Diseases and Sciences, vol. 57, no. 12, pp. 3106-3115, 2012. 
[81] L. C. Schneider, G. G. Perez, S. R. Banzi et al., "Evaluation of the effect of Ginkgo biloba extract (EGb 761) on the myenteric plexus of the small intestine of Wistar rats," Journal of Gastroenterology, vol. 42, no. 8, pp. 624-630, 2007.

[82] G. G. Perez, L. C. L. Schneider, and N. C. Buttow, “Ginkgo biloba (EGb 761) extract: effects on the myenteric plexus of the large intestine in wistar rats," Digestive Diseases and Sciences, vol. 54, no. 2, pp. 232-237, 2009.

[83] A. P. T. Veit and J. N. Zanoni, "Age-related changes in myosin$\mathrm{V}$ myenteric neurons, CGRP and VIP immunoreactivity in the ileum of rats supplemented with ascorbic acid," Histology and Histopathology, vol. 27, no. 1, pp. 123-132, 2012. 


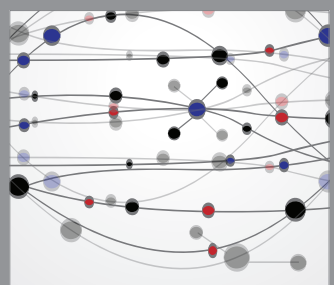

The Scientific World Journal
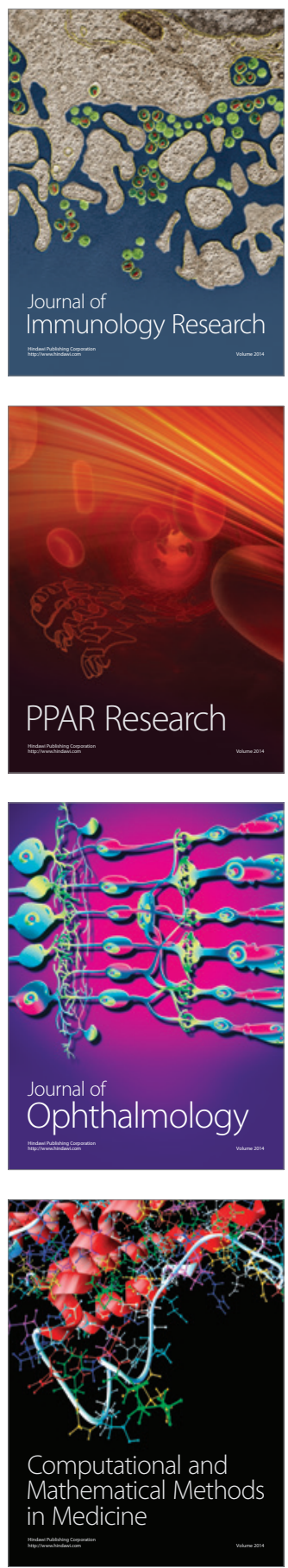

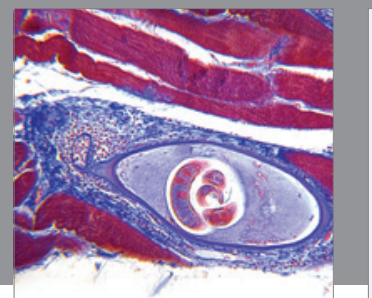

Gastroenterology

Research and Practice
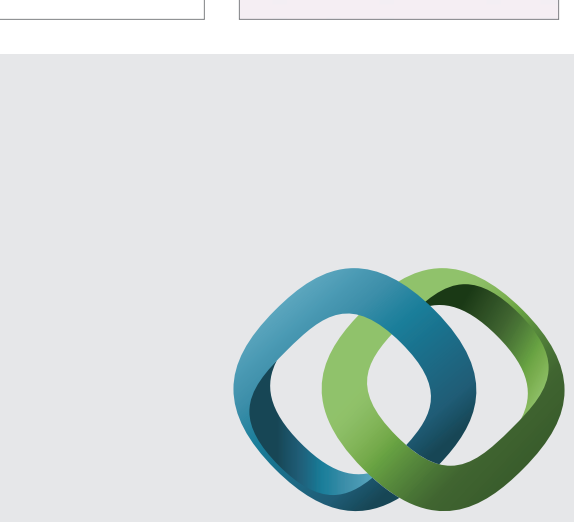

\section{Hindawi}

Submit your manuscripts at

http://www.hindawi.com
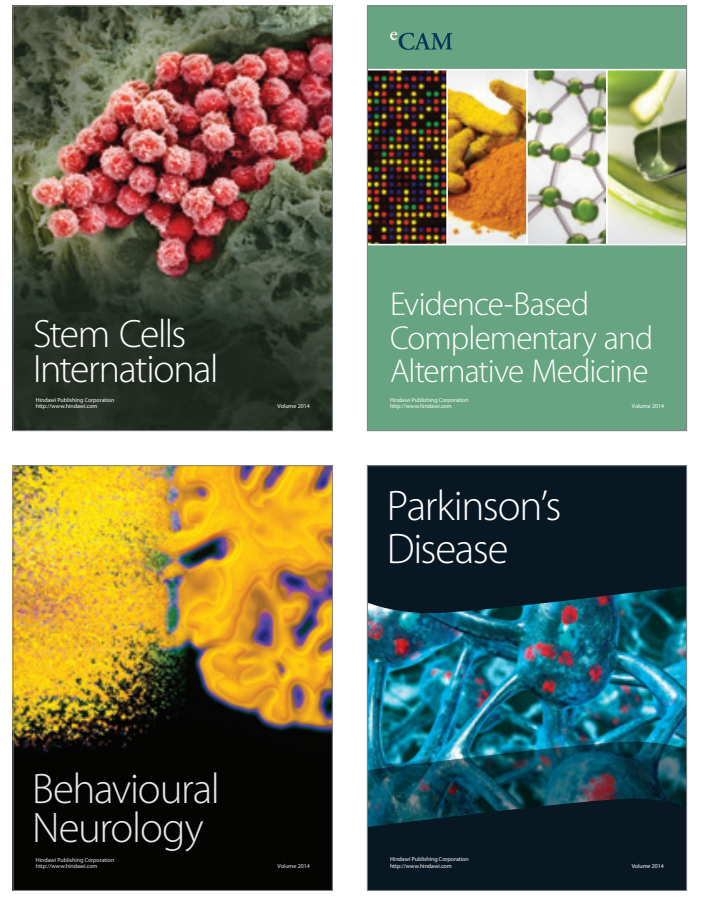
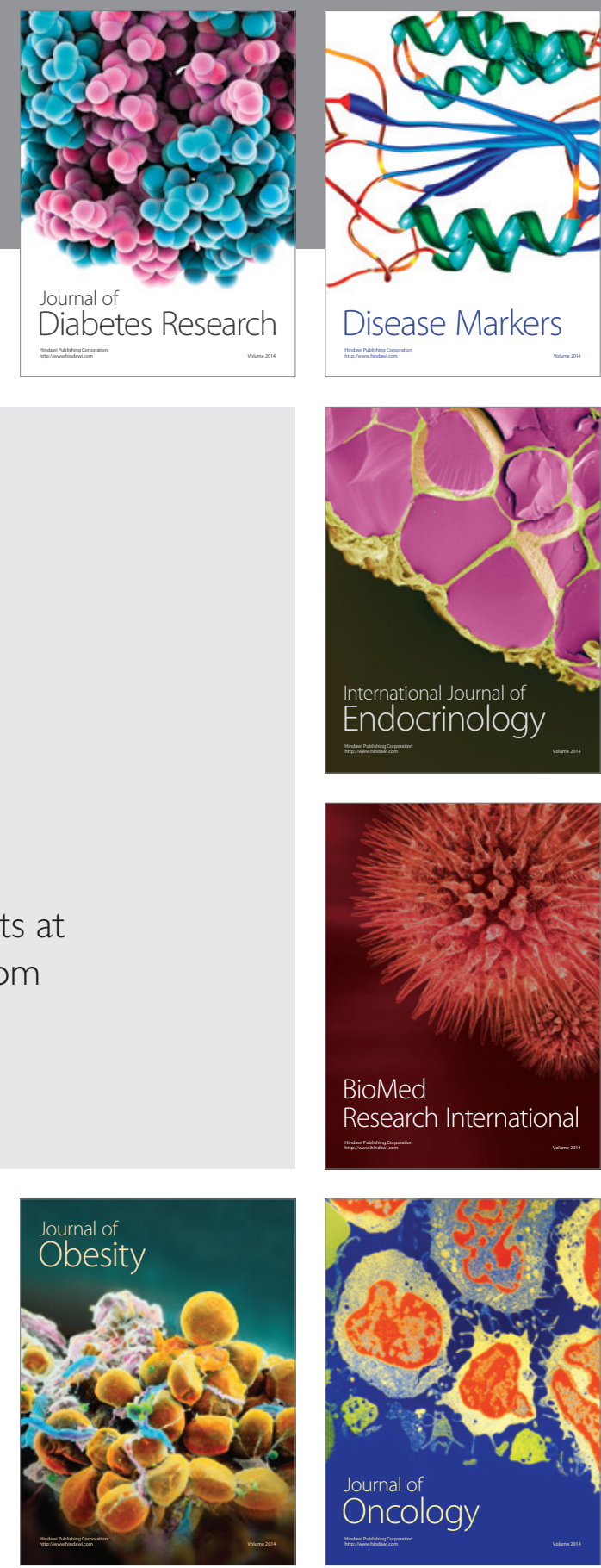

Disease Markers
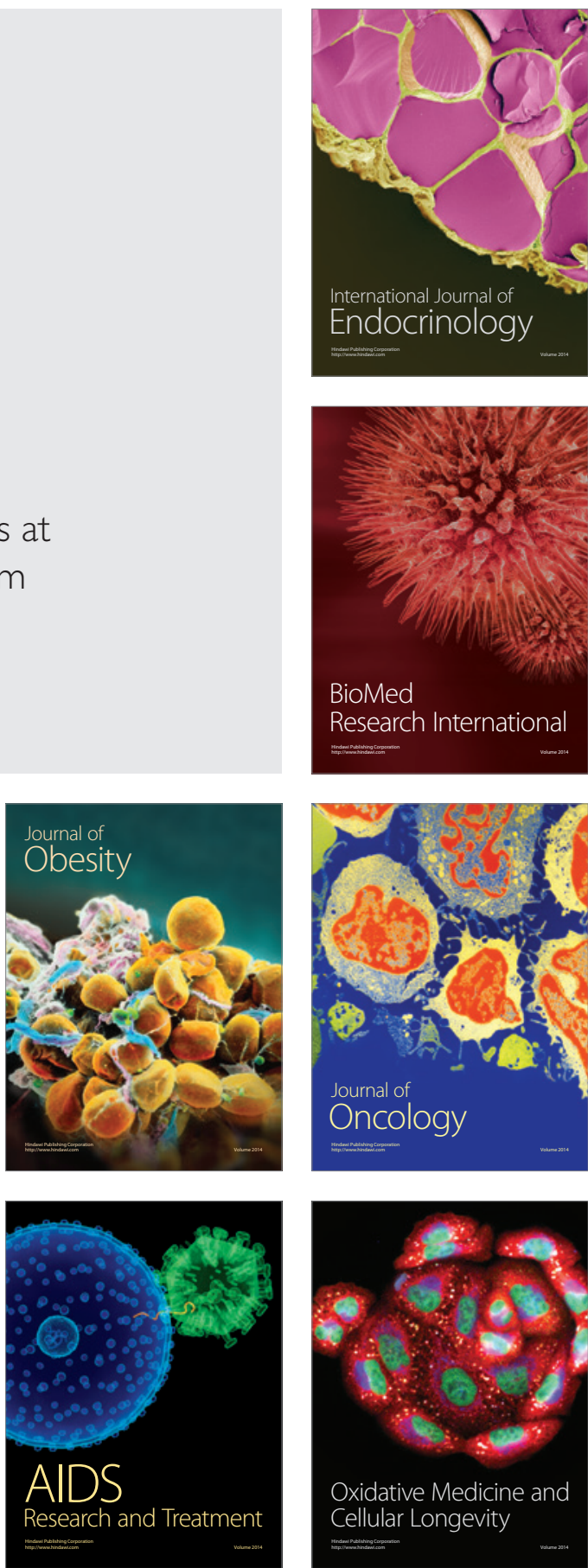